\title{
The Effect of Happiness, Emotional Intelligence, Spiritual Intelligence, and Work Culture on The Performance of The Staff of The Election Commission of Kerinci Regency and Sungai Penuh City
}

\author{
${ }^{1 \text { st }}$ Karyadi $^{1},{ }^{\text {2nd }}$ Aldri Frinaldi ${ }^{2}$ \\ \{karyadii037@gmail.com $\left.{ }^{1}, \underline{\text { aldri@fis.unp.ac.id }}{ }^{2}\right\}$
}

Department of Magister Public Administration, Universitas Negeri Padang, Padang, Indonesia ${ }^{1}$

Department of Public Administration, Universitas Negeri Padang, Padang, Indonesia ${ }^{2}$

\begin{abstract}
The objective of this study was to examine the effect of happiness, emotional intelligence, spiritual intelligence, and work culture on the performance of the staff of the KPU of Kerinci Regency and Sungai Penuh City. The effects are seen partially and simultaneously. The research was conducted at the KPU of Kerinci Regency and Sungai Penuh City by using an associative quantitative approach. The participants of this study were all the commissioners and staff of the KPU of Kerinci Regency and Sungai Penuh City consisting of 78 people. The sampling technique used quota sampling. The data were collected using a validated and reliable questionnaire. The data were analyzed using multiple regression analysis after the classical assumption test was previously carried out. The regression analysis conducted in this study showed that the analytical model can be used as an academic reason to strengthen the theories and models that are reviewed in the present research study. The results proved that the variables of happiness, emotional intelligence, spiritual intelligence, and work culture have significant effects on the performance of the staff of the KPU of Kerinci Regency and Sungai Penuh City either partially or simultaneously. The simultaneous influence contribution is $96.5 \%$, while the partial influence of each variable has a different level of contribution of influence on the performance.
\end{abstract}

Keywords: Happiness, Emotional Intelligence, Spiritual Intelligence, Work Culture, Performance

\section{Introduction}

In running an organization, the government requires reliable human resources because human resources are vital and very decisive. Without qualified human resources, the government organization will not run well. Human resources with intelligence, talents, energy, desire, knowledge, feelings, and creativity are needed by government organizations to achieve the organization's vision and mission and improve performance.

Problems related to performance are the problems that will always be faced by the management of the organization. Therefore, leaders need to know the factors that affect performance. The factors that can affect performance will make the organization managers take 
necessary policies to improve the performance of human resources to match the expectations of the organization [1].

Many factors can affect human resource performance. According to Simamora (1995), performance is influenced by three factors, i.e. individual factors, psychological factors, and organizational factors. Wirawan (2009) explained that human resource performance is the product of a synergy of three factors, namely internal employee factors, internal organizational factors, and external factors. Meanwhile, according to Davis cited in Mangkunegara, the factors that influence human resource performance in an organization are ability and motivation. [3]

Human resource performance is not only seen from perfect workability but also from the ability to master and manage oneself as well as to build relationships with others. This ability is called emotional intelligence (Goleman, 2002). [5] Goleman (2002:46) said that 80\% of a person's success is determined by emotional intelligence, while the other $20 \%$ is determined by IQ (Intelligence Quotient). Furthermore, Goleman (2002) stated that emotional intelligence is the capability to monitor and control the feelings of oneself and others and use these feelings to guide thoughts and actions [5]. Therefore, emotional intelligence is central for success in work and producing outstanding performance at work. People who have emotional intelligence will be able to face challenges and make a person who is full of responsibility, productive, and optimistic in dealing with and solving problems, where these things are needed in the work environment.

Another form of intelligence is spiritual intelligence. Spiritual intelligence allows a person to think creatively, be provident, generate, or even change rules, making that person perform better. Zohar dan Marshal (2001:23) said that spiritual intelligence can make individuals intellectually, emotionally, and spiritually intact. To be clever is not only said to have high knowledge, but to be truly smart, one must possess spiritual intelligence.

The emotional and spiritual intelligence possessed by each individual is undoubtedly varied from one another. These traits can be a characteristic or personal identity of the employee. Just like individuals, organizations also have certain characteristics that can define whether an organization is good or not. Through these characteristics, we can learn the character of an organization, the nature and behavior at work that we can call a work culture. That way, it can be said that the organization also has a work culture that regulates how its members perform to attain a predetermined goal. Work culture is one of the factors that can affect performance in an organization. This factor is closely associated with improved performance because by attaining a good work culture, supported by cooperation with fellow organizational members, performance improvement will be achieved (Tika, 2008:120).

For this reason, the awareness of organizational members on the significance of work culture still needs to be socialized. This has to do with the implementation of a very intricate work culture on performance because organizational members have diverse characteristics. Inadequate abilities, attitudes, and behavior still need to be enhanced. Moreover, motivation from leadership is required.

Another variable that can support performance is happiness as a way to reach utmost performance by working according to one's potential and realizing the happiness that exists in oneself and co-workers. According to Keser (2016), happiness is a special mindset that helps someone to work optimally and make the most of existing potential. Happiness is usually defined by how people experience and appraise their life as a whole. Since most people spend a large part of their life at work, it is essential to gain a firm understanding of the role of work and the workplace in determining individual happiness (Neve \& Ward, 2017).

The results of a study conducted by Fisher (2010) showed that someone feels happy when he can work with satisfying results rather than average results [10]. Organizational members 
who feel happy at work due to their good work performance can be seen from their comfort in the environment, discipline for work, and the results of the work they have achieved. This is also in accordance with what Pryce and Jones' (2014) statement, that increased work performance and productivity derive from a steady and strong relationship of happiness, not just smiling and positive thinking.

Happiness has a positive impact on the organization. When the members of the organization feel comfortable when working, the performance will be optimal and has an impact on work productivity (Vallina \& Alegre, 2018). Happy employees will bring benefits to themselves because they work with quality abilities so that they have sufficient income, and the organization will feel a positive impact through improved performance.

The object of this research was the staff of the KPU of Kerinci Regency and Sungai Penuh City, an institution that is elected and determined by law as the organizer of the General Election. At the beginning of its formation, the KPU is an institution consisting of non-partisan people and most of them are among universities and non-governmental organizations. The Regency/City Election Commission is the organizer of general elections in the City District that has a hierarchical affiliation with the Provincial General Election Commission and the General Election Commission of the Republic of Indonesia, which functions to hold general election stages (Samsul Wahidin, 2008: 47).

The KPU of Kerinci Regency and Sungai Penuh City has made efforts to improve their performance. However, in the field, it was still found that the performance of the employees was not optimal yet. This was in accordance with the field data based on the results of interviews and preliminary observations conducted by the researchers at the KPU of Kerinci Regency and Sungai Penuh City. This could be seen and was a phenomenon that occured at the location of the research. First, there was still a lack of awareness of working time discipline by the KPU employees of Kerinci Regency and Sungai Penuh City at work. The time specified for work was not carried out following the actual working time. The KPU of Kerinci Regency and Sungai Penuh City set employee working hours with Monday to Thursday working hours from 07.30 WIB to $16.00 \mathrm{WIB}$, rest hours 12.00-13.00 WIB, and Friday working hours from 07.00 WIB to 16.30 WIB rest from 12.00 to 13.30 WIB. However, what happened was that there were employees who were less disciplined with the assigned time regulations by chatting in the canteen and leaving the office during working hours.

Second, there was seniority in doing work at the KPU Secretariat of Kerinci Regency and Sungai Penuh City, where senior employees have more authority than others, so that the work was only done by a handful of employees. This condition would more or less affect the happiness of the employees themselves. Mrs. Lusi Videska Irawan, S.Sos., the Head of the General Election Commission, Finance and Logistics of the KPU of Kerinci Regency, in an interview said that the KPU of Kerinci Regency and Sungai Penuh City still have seniority due to respect for the employees who have higher positions and the work is carried out only by certain employees, according to their respective procedures and parts. So that the work is done must be handled directly by the person concerned.

Third, there was a lack of direct supervision of the work carried out by the ranks under the KPU of Kerinci Regency and Sungai Penuh City, such as the District Election Committee, the Voting Committee, and the Voting Organizing Group. This is based on an interview with Mr. Zamzami as the Head of the Technical Subdivision of the KPU Sungai Penuh. He said that election organizers at the sub-district and village levels must be accountable hierarchically to the KPU of Kerinci Regency and Sungai Penuh City and to report all work processes that take place in the field to the KPU of Kerinci Regency and Sungai Penuh city. However, in reality, 
there were still officials in the District and Villages that were still negligent in carrying out their duties due to the lack of assistance from the KPU of Kerinci Regency and Sungai Penuh City.

Fourth, the application used was still constrained by a weak internet network, so it took a long time in an election stage. This was based on an interview with Mr. Dede Setiawan, S.Kom., M.Sc., as the Head of Sub Division of Program and Data for the KPU of Kerinci Regency. He said that because the internet network was still weak, applications in updating voter data were often disrupted, causing difficulties in determining the voter list.

In addition to several problems related to performance in the KPU of Kerinci Regency and Sungai Penuh City, the results of observations by researchers on existing human resources indicate that within organizations, there are still differences in income and allowances received by each member. This will undoubtedly have an impact on the happiness of organizational members. It seems that there were still gaps in the mastery of existing technology; some employees were less able to manage their emotion, which has an impact on organizational performance where there are still complaints about the performance of the staff of the KPU of Kerinci Regency and Sungai Penuh City. Besides, some employees argued that they could not control emotion at work so that in completing complex work, they became unfocused and lack initiative in completing certain tasks.

Regarding spiritual intelligence, it can be seen that some members of the organization worked alone - solely responsible for the leadership. Even though the real responsibility at work is to God Almighty, there were still employees who have poor character, such as calling out loud to colleagues.

Based on the description above, it is urgent to research the influence of happiness, emotional intelligence, spiritual intelligence, and work culture on the performance of the staff of the KPU of Kerinci Regency and Sungai Penuh City.

\section{Methodology}

The research was conducted at the KPU of Kerinci Regency and Sungai Penuh City using an associative quantitative approach. The participants of this study were all commissioners and secretariat staff of the KPU of Kerinci Regency and Sungai Penuh City consisting of 78 people. The sampling technique used quota sampling. The data were collected using an instrument in the form of a questionnaire, which was developed based on indicators of variables. The questionnaire had previously been tested for validity and reliability. The data collection technique also used documentation study techniques using primary and secondary data. The data were analyzed using multiple regression analysis after the classical assumption was tested.

\section{Findings and Discussion}

The results of this research were analyzed using multiple regression analysis. Before the data were processed, the prerequisites were tested with the classical assumption test that consist of 1) normality test, 2) linearity test, 3) heteroscedasticity test, and 4) multicollinearity test. The classical assumption tests analysis met the requirements so that the data were declared feasible for regression test analysis. The results of the data regression test are presented in Table 1 below: 
Table 1. Regression Test Results

\begin{tabular}{|c|c|c|c|c|}
\hline Model & $\mathbf{R}$ & R Square & $\begin{array}{c}\text { Adjusted R } \\
\text { Square }\end{array}$ & Sig. \\
\hline $\begin{array}{l}\text { 1. The influence of happiness, emotional intelligence, spiritual } \\
\text { intelligence, and work culture on the performance of the } \\
\text { General Election Commission of Kerinci Regency and Sungai } \\
\text { Penuh City. }\end{array}$ & $.983^{\mathrm{a}}$ & .967 & .965 & .000 \\
\hline $\begin{array}{l}\text { 2. The effect of happiness on the performance of the General } \\
\text { Election Commission of Kerinci Regency and Sungai Penuh } \\
\text { City }\end{array}$ & $.370^{\mathrm{a}}$ & .137 & .126 & .001 \\
\hline $\begin{array}{l}\text { 3. The influence of emotional intelligence on the performance of } \\
\text { the General Election Commission of Kerinci Regency and } \\
\text { Sungai Penuh City }\end{array}$ & $.191^{\mathrm{a}}$ & .137 & .124 & .013 \\
\hline $\begin{array}{l}\text { 4. The influence of spiritual intelligence on the performance of } \\
\text { the General Election Commission of Kerinci Regency and } \\
\text { Sungai Penuh City }\end{array}$ & $.954^{\mathrm{a}}$ & .911 & .910 & .000 \\
\hline $\begin{array}{l}\text { 5. The influence of work culture on the performance of the } \\
\text { General Election Commission of Kerinci Regency and Sungai } \\
\text { Penuh City }\end{array}$ & $.975^{\mathrm{a}}$ & .952 & .951 & .000 \\
\hline
\end{tabular}

The table above displays the magnitude of the influence and the size of the contribution of each independent variable to the dependent variable. The results of statistical data processing tests proved that each independent variable has a significant effect on the performance of the staff of the KPU of Kerinci Regency and Sungai Penuh City. This was proven by the acquisition of a significant value that is below $<0.05$. The significance here also means that the effect of each independent variable on the dependent variable has a significant effect. The contribution of influence given is, of course, different for each variable. However, it can be concluded that the biggest contribution occurred in the work culture variable with an influence contribution of 95.1\%. Meanwhile, the smallest influence among the independent variables is the emotional intelligence variable with a contribution of only $12.4 \%$.

\section{a. The Influence of Happiness, Emotional Intelligence, Spiritual Intelligence, and Work Culture on Performance}

The first hypothesis in this study is that there is an effect of happiness, emotional intelligence, spiritual intelligence, and work culture on the performance of the staff of the KPU of Kerinci Regency and Sungai Penuh City. The results showed that the hypothesis was proven. This was proven by the acquisition of a significance value of $0.000<0.05$. The test results show that the significance value ( $F$ test) is obtained with a value of 0.000 , thus the significance value obtained is smaller than the assigned $\alpha$ probability $(0.000<0.05)$.

Based on the results of the statistical tests described above, the researchers obtained an illustration that the influence of happiness, emotional intelligence, spiritual intelligence, and work culture has contributed significantly to the improvement of the staff's performance in the KPU of Kerinci Regency and Sungai Penuh City. The test results indicate that the research hypothesis, which states that 'there is an effect of happiness, emotional intelligence, spiritual intelligence and work culture on the performance of the staff of the KPU of Kerinci Regency and Sungai Penuh City', can be tested empirically and the hypothesis was proven. This suggests 
that the theory used to analyze problems in the field is true and was proven in this study. Therefore, it can be concluded that the theory is still quite actual and relevant so that this research does not generate new theories or invalidate existing theories. Rather, it strengthens the theories used by researchers.

\section{b. Effects of Happiness on Performance}

The second hypothesis of this study is that there is an effect of happiness on the performance of the staff of the KPU of Kerinci Regency and Sungai Penuh City. Based on the results of data analysis using the SPSS 25.0 for windows program, it was found that happiness has a partially significant effect on the performance. This is indicated by the count value of 3.476 which is actually smaller than the critical value $(3.476<1.992)$ or the probability $t$ is smaller than $0.05(0.001>0.05)$, which means that happiness has a significant effect on the performance of the staff of the KPU of Kerinci Regency and Sungai Penuh City.

The results of this study support the results of previous research conducted by Wijayanto (2017) entitled 'The Influence of Organizational Climate on Employee Happiness and Performance', which proved that there is a positive and significant influence of the happiness variable on employee performance. The results of this study are also in accordance with Spreitzer and Porath's (2012) opinion, which states that an organization whose employees are very passionate and happy is proven to have a significant influence on the improvement of company performance.

According to Lyubomirsky et al. (2005), a happy person can instantly respond to any condition more positively and harmoniously and has a lower level of stress and a better immune system than an unhappy person. In his research, Fisher (2010) found a lot of indications that happiness has important impacts on employee performance and work productivity, both individually and within an organization.

Based on the results of the statistical test as described above, it appears that the effect of happiness empirically has contributed significantly to the improvement of the performance of employees in the KPU of Kerinci Regency and Sungai Penuh City. The test results indicated that the research hypothesis that states that 'there is a significant effect of happiness on the performance of the staff of the KPU of Kerinci Regency and Sungai Penuh City' can be tested empirically and the hypothesis was proven. This suggests that the theory used to analyze problems in the field is true and was proven in this study. Therefore, it can be concluded that the theory is still quite actual and relevant so that this research does not generate new theories or invalidate existing theories. Rather, it strengthens the theories used by researchers.

\section{c. The Effect of Emotional Intelligence on Performance}

The third hypothesis tested in this study is that there is an effect of emotional intelligence on the performance of the staff of the KPU of Kerinci Regency and Sungai Penuh City. The results of data analysis using the SPSS 25.0 for windows program show that there is an effect of emotional intelligence on the performance. This is indicated by the t value of 2.542 , where the value of the t-test statistic ( $t)$ is greater than the critical value $(2.542>1.992)$ or the probability of $t$ is less than $0.05(0.013<0.05)$. This means that emotional intelligence has a significant effect on the performance of the staff of the KPU of Kerinci Regency and Sungai Penuh City.

Goleman (2005) stated that emotional intelligence can motivate oneself, survive frustration, control impulses, and keep the burden of stress from paralyzing the mind, empathizing, and praying. So it can be said that the staff of the KPU of Kerinci Regency and 
Sungai Penuh City can have a high performance if they can motivate themselves, have empathy, pray, and control their feelings.[15]

The results of this study also support the opinion expressed by Sarwono (2009) who said that emotion is very influential on performance because people are emotional, they will not be able to think well, regardless of their intellectual levels. Robbins (2008) said various studies suggest that Emotional Intelligence can play an important role in implementing work and characterize high-performing people or qualified humans. Employees with good emotional intelligence have personal and social abilities such as empathy, self-discipline, and initiative so that they will produce better performance than employees with lower emotional intelligence [17].

Likewise, the theory put forward by Agustian (2001: 56) says that people who have only brain intelligence or many who have high degrees are not automatically successful in their work, or worse, are eliminated because of their low emotional intelligence and their hearts. Agustian (2001) concluded that emotional intelligence is the main key to success in supporting one's performance.

The results of this study also support the results of research conducted by Trihandini (2005) with the title 'Analysis of the Effect of Intellectual Intelligence, Emotional Intelligence and Spiritual Intelligence on Employee Performance', which resulted in the conclusion that emotional intelligence and spiritual intelligence have a significant positive effect on performance [19].

Based on the results of of statistical tests described above, the researchers get an idea that the influence of emotional intelligence has made a significant contribution to improving the performance of employees in the KPU of Kerinci Regency and Sungai Penuh City. The test results indicate that the research hypothesis, which states that 'there is an effect of emotional intelligence on the performance of the staff of the KPU of Kerinci Regency and Sungai Penuh City', can be tested empirically and the hypothesis was proven. Similar to the two variables described previously, this result suggests that the theory used to analyze problems in the field is true and was proven in this study. Therefore, it can be concluded that the theory is still quite actual and relevant so that this research does not generate new theories or invalidate existing theories. Rather, it strengthens the theories used by researchers.

\section{d. The Effect of Spiritual Intelligence on Performance}

The fourth hypothesis in this study is that there is an effect of spiritual intelligence on the performance of the staff of the KPU of Kerinci Regency and Sungai Penuh City. The results of the study showed the influence of the spiritual intelligence variable on the performance with the count value of 27.874. Therefore, the statistical t-test price (count) was greater than the critical value $(27.874>1.992)$ or the probability of $t$ was smaller than $0.05(0.000<0.05)$. It means that spiritual intelligence has a significant effect on the performance of the staff of the KPU of Kerinci Regency and Sungai Penuh City.

Spiritual intelligence assimilates all human intelligence. It makes people truly intellectually, emotionally, and spiritually intact beings. From the information above, it can be seen that spiritual intelligence also plays a role in our brains. Spiritual intelligence is also very influential on performance; high spiritual intelligence will produce a good performance as well. Spiritual intelligence teaches people to express and give meaning to every action, so if you want to show good performance, spiritual intelligence is required.

The research results also support the theory put forward by Agustian (2001). He concluded that in Islam, matters related to spiritual skills such as consistency (istiqamah), humility (tawadlu), trying and surrendering (tawakal), sincerity, totality (kaffah), balance (tawazun), and integrity and perfection (ihsan), all of which are called Akhlakul Karimah. In spiritual 
intelligence, these things are used as yardsticks for spiritual intelligence, so that it influences one's performance. According to Hoffman (2002:133), those who can give meaning to their lives and bring spirituality into their work settings will make them better people, so that the subsequent performance is also better.

Based on the results of statistical tests described above, the researchers got an idea that the influence of spiritual intelligence has made a significant contribution to improving the performance of employees in the KPU of Kerinci Regency and Sungai Penuh City. The test results show that the research hypothesis which states that 'there is an effect of spiritual intelligence on the performance of the staff of the KPU of Kerinci Regency and Sungai Penuh City' can be tested empirically and the hypothesis was proven. Based on the results of the research and discussion above, and if it is connected with the theory used to analyze problems in the field, it can be said that the theory is correct and was proven in this study. Thus, it can be concluded that the theory is still quite actual and relevant, so that this research does not produce new theories or invalidate existing ones. Rather, it strengthens the theories used by researchers.

\section{e. Effect of Work Culture on Performance}

The final or fifth hypothesis tested in this study is that there is an influence of work culture on the performance of the staff of the KPU of Kerinci Regency and Sungai Penuh City. Based on the results of the study, work culture has a significant effect on the performance, as evidenced by the $t$ count value, which is greater than the table $(38.630>1.992)$ or the probability $t$ is smaller than $0.05(0.000<0.05)$.

The results of hypothesis testing show that the work culture variable has a significant influence on the performance of the staff of the KPU of Kerinci Regency and Sungai Penuh City. These results indicate that, in order to improve performance, it is necessary to have a good work culture in an organization that support good behavior relationships among people.

The work culture of the staff of the KPU of Kerinci Regency and Sungai Penuh City is already good, so it needs to be maintained and improved. What has been created can be even better so that organizational members can always be consistent in improving their performance. As stated by Schein (2014), work culture is a pattern of basic suppositions that are formed, discovered, or established by certain groups as learning to overcome problems of external adaptation and internal integration that take place in organizations and are proven to be able to affect performance.

The same opinion was expressed by Supriyadi and Triguno (2011), work culture is a philosophy that views life based on the values that characterize, habits, and drivers instilled in a group and attitudes in behavior, ideals, opinions, views, and actions that are exhibited as work. This was proven by the results of the present research.

A study conducted by Kotter and Heskett (1992) entitled 'Corporate Culture and Performance' concluded that: Work culture has a very fundamental connection with the success or failure of the organization that builds its members' performance; Work culture has a positive influence on the company's economic performance; Organizational culture can be formed and shaped to increase organizational performance. This means that work culture does not directly affect the performance of an organization, and the results of this study proved so.

The results of this study are supported by the results of previous research conducted by [24] entitled 'The Effect of Work Culture and Physical Work Environment on Employee Performance (Studies on Employees of PT. Semen Indonesia (Persero Tbk)', which shows that work culture has a significant effect on employee's performance. The results of the present study were also similar to the results obtained in a study conducted by Kurniawan et al. (2012) with the title 'The Effect of Work Culture and Work Motivation on Employee Performance 
International Federation Red Cross (IFRC) Banda Aceh, which showed that work culture and motivation simultaneously have a significant effect on the employees' performance.

Based on the results of statistical tests as described above, the researchers get an idea that the influence of work culture has made a significant contribution to improving employees' performance in the KPU of Kerinci Regency and Sungai Penuh City. The test results indicate that the research hypothesis that states that 'there is an influence of work culture on the performance of the staff of the KPU of Kerinci Regency and Sungai Penuh City' can be tested empirically and the hypothesis was proven. Related to the theory used to analyze problems in the field, then the researchers have an opinion that the theory is true and it was proven in this study. It can be concluded that the theory is still quite actual and relevant so that this research does not produce new theories or invalidate existing theories. Rather, it strengthens the theories used by researchers.

\section{Conclusion}

From the results of the above research, it can be concluded that there is a significant influence of the variables of happiness, emotional intelligence, spiritual intelligence, and work culture on the performance of the staff of the KPU of Kerinci Regency and Sungai Penuh City, as proven by the significant value of each independent variable on the dependent variable, which is smaller than 0.05. The contribution of the influence of each variable is different, but it can be concluded that the greatest contribution of influence occurs in the work culture variable with an influence contribution of $95.1 \%$. In contrast, the least influence among the independent variables is the emotional intelligence variable with a contribution of influence of only $12.4 \%$. Furthermore, the magnitude of the effects of happiness, emotional intelligence, spiritual intelligence, and work culture on the performance of the staff of the KPU of Kerinci Regency and Sungai Penuh City are simultaneous, as shown in the SPPS model summary output, the Adjusted R Square value is 0.965 or $96.5 \%$, and the remaining $3.5 \%$ is influenced by other variables outside the variables studied.

Based on the results of this study, the authors suggest that the KPU of Kerinci Regency and Sungai Penuh City continue to maintain and increase happiness, emotional intelligence, spiritual intelligence, and work culture as the results of the study proved that there is a significant influence of each variable on performance. It is also suggested to further researchers examine other variables that affect performance in election management institutions by using indicators that are more comprehensive and in accordance with several previous theories and research.

\section{References:}

[1] S. Habibah, "Meningkatkan Kinerja Melalui Mekanisme 360 Derajat", J. Telaah Bisnis, vol 2, no 1, bll 27-37, 2001.

[2] Simamora, kebiajakan Kinerja Karyawan. Yogyakarta: BPFEE, 1995.

[3] Wirawan, Evaluasi Kinerja Sumber Daya Manusia Teori Aplikasi dan Penelitian. Jakarta: Salemba Empat, 2009.

[4] K. Davis, Newstron, en J. W, Human Behavior At Work: Organizational Behavior. New York: McGraw Hill International, 1989.

[5] D. Goleman, Emotional Intelligence (Terjemahan). Jakarta: PT Gramaedia Pustaka Utama, 2002. 
[6] D. Zohar en M. Ian, SQ Kecerdasaan Spiritual. Bandung: Mizan, 2001.

[7] W. Samsul, Hukum Pemerintahan Daerah Mengawasi Pemilihan Umum Kepala Daerah, Cetakan 1. Yogyakarta: Pustaka Pelajar, 2008.

[8] A. Keser, "Happiness At Work: Survey From Turkey", in The 2016 International Academic Research Conference in London, 2016, bll 295-301.

[9] J. Neve, D. E, en G. Ward, . "Happiness at Work. Centre for Economic Performance. Centre for Economic Performance London School of Economics and Political Science", $J$. Econimic Polit., no 1474, bll 1-72, 2017.

[10] P. T. Fisher en B. Murphy, Spring Persistence with Hibernate. New York: Springer Science Business Media, LLC, 2010.

[11] A. S. Vallina en J. Alege, "Happiness at work: Developing a shorter measure", J. Manage., bll 1-21, 2018, doi: 10.1017/jmo.2018.24.

[12] S. A. Wijayanto, "Dampak Iklim Organisasi Terhadap Kebahagiaan dan Kinerja Karyawan (Studi Pada Universitas Muhammadiyah Yogyakarta)", JBMA, vol 4, no 1, 2017.

[13] G. Spreitzer en C. Porath, "Creating Sustainable Performance", Harvard Business Review, 2012. http://hbr.org/2012/01/creating-sustainableperformance/ar/pr.

[14] S. Lyubomirsky, K. M. Sheldon, en D. Schkade, "Pursuing Happiness: The Architecture of Sustainable Change", J. Rev. Gen. Psychol., vol 9, no 2, bll 1-47, 2005.

[15] D. Goleman, Kecerdasan Emosi: Untuk Mencapai Puncak Prestasi. Terjemahan Alex Tri Kantjono. Jakarta: PT Gramaedia Pustaka Utama, 2005.

[16] S. W. Sawono, Psikologi Remaja. Jakarta: Rajawali Pers, 2009.

[17] P. S. Robbins en C. Mary, Manajemen, Diterjemahkan Oleh Bob Sabran, Wibi Hardani. Jakarta: Erlangga, 2008.

[18] A. G. Agustian, Rahasia Sukses Membangun Kecerdasan Emosi dan Spiritual - ESQ. Jakarta: Arga, 2001.

[19] R. A. Trihandini en M. Fabiola, “Analisis Pengaruh Kecerdasan Intelektual, Kecerdasan Emosi, dan Kecerdasan Spiritual terhadap Kinerja Karyawan (Studi Kasus di Hotel Horison Semarang)", Universitas Dipenogoro, 2005.

[20] M. L. Hoffman, Empathy and Moral Development. United Kingdom: Cambridge University Press, 2002.

[21] E. H. Schein, Organizational Culture and Leadership. San Fransisco: Josey-Bass Publishers, 2014

[22] G. Supriyadi en Triguno, Budaya Kerja Organisasi Pemerintah. Jakarta: Pustaka Pelajar, 2011.

[23] Kotter en Hesket, Corporate Culture and Performance. New York: The Free Press, 1992.

[24] N. N. Nasyadizi, R. Kusdi, en R. Ika, "Pengaruh Stres Kerja dan Kepuasan Kerja Terhadap Kinerja Karyawan (Studi Pada Karyawan PT. Jasa Raharja (Persero) Cabang Jawa Timur di Surabaya)", Univertas Brawijaya, 2016.

[25] D. Kurniawan en Dkk, "Pengaruh Budaya Kerja dan Motivasi Kerja Terhadap Kinerja Karyawan International Feeration Red Cross (IFRC) Banda Aceh.”, vol 1, no 1, bll 1-15, 2012. 